\title{
Investigation of the protective effect of enoxaparin and ticagrelor pretreatment against ischemia-reperfusion injury in rat lung tissue
}

\author{
(iD) Orhan FIndik ${ }^{1}$ \\ (D) Melda Yardımoglu Yılmaz ${ }^{2}$ \\ (iD) Yusufhan Yazır ${ }^{2}$ \\ D Selenay Furat Rençber ${ }^{2}$ \\ (iD) Kübra Kavram Sarıhan ${ }^{2}$ \\ (iD) Atike Tekeli Kunt ${ }^{3}$
}

\begin{abstract}
1. Department of Cardiovascular Surgery, Derince Education and Research Hospital, Kocaeli, Turkey. 2. Department of Histology and Embryology, Faculty of Medicine, Kocaeli University, Kocaeli, Turkey. 3. Department of Cardiovascular Surgery, Health Sciences University Ankara Numune Training and Research Hospital, Ankara, Turkey
\end{abstract}

\section{SUMMARY}

OBJECTIVES: This study was conducted to reveal the possible protective effects of ticagrelor and enoxaparin pretreatment against ischemia-reperfusion (IR)-induced injury on the lung tissue of a rat model.

METHODS: Wistar albino rats were randomly divided into 4 groups as follows: group-1 (control-sham), group-2 (control-saline+IR), group-3 (ticagrelor+IR), group-4 (enoxaparin+IR). Before the ischemic period, saline, ticagrelor, and enoxaparin were administered to the 2nd-4th groups, respectively. In these groups, IR injury was induced by clamping the aorta infrarenally for $2 \mathrm{~h}$, followed by $4 \mathrm{~h}$ of reperfusion except group-1. After the rats were euthanized, the lungs were processed for histological examinations. Paraffin sections were stained with Haematoxylin\&Eosin (H\&E) for light microscopic observation. Apoptosis was evaluated by caspase-3 immunoreactivity. Data were statistically analyzed using the SPSS software.

RESULTS: In the lung sections stained with H\&E, a normal histological structure was observed in group-1, whereas disorganized epithelial cells, hemorrhage, and inflammatory cell infiltration were seen in the alveolar wall in group-2. The histologic structure of the treatment groups was better than that of group-2. Caspase-3(+) apoptotic cells were noticeable in sections of group-2 and were lower in the treatment groups. In group-4, caspase-3 immunostaining was lower than in group-3. In group-2, apoptotic cells were significantly higher than in the other groups $(p<0.001)$.

CONCLUSION: Based on the histological results, we suggested that both therapies ameliorated the detrimental effects of IR. Caspase-3 immunohistochemistry results also revealed that pre-treatment with enoxaparin gave better results in an IR-induced rat injury model. In further studies, other parameters such as ROS and inflammatory gene expressions should be evaluated for accurate results.

KEYWORDS: ischemia-reperfusion, rat lung tissue, caspase-3, apoptosis.

\section{INTRODUCTION}

Aortic surgery with clamping of the thoracic or thoracoabdominal aorta causes rapid and significant physiologic changes that can result in major complications in several organ systems. Cross-clamping can also contribute to pulmonary complications, al- though the mechanisms for this effect are complex and not fully understood'. The cross-clamping of the aorta is called 'ischemia', and the declamping after completion of the anastomosis is 'reperfusion'. Reperfusion causes both local and systemic damage,

DATE OF SUBMISSION: 13-Feb-2019

DATE OF ACCEPTANCE: 31-Mar-2019

CORRESPONDING AUTHOR: Melda Yardimoğlu Yilmaz

Kocaeli University, Faculty of Medicine Histology and Embryology Department - Kocaeli, 41380 Turkey.

Tel:+902623037343 - Fax: +902623038740

E-mail: melda.yardimoglu@gmail.com 
particularly through inflammatory mediators, and often by a rapid release of $\mathrm{O}_{2}$-free radicals from polymorphonuclear leukocytes ${ }^{2,3}$. These products can cause terrible complications during reperfusion and even death due to systemic inflammatory response and multiple organ failure ${ }^{4}$.

Distant organ damage and reperfusion after ischemia are mainly seen in the lung, kidney, and heart. Pathophysiological manifestations of aortic clamping resulting in hemodynamic compromisation were summarized by Katseni et al. ${ }^{5}$, and Kalogeris et al. ${ }^{6}$ reported the mechanisms contributing to tissue injury in ischemia/reperfusion (IR) as follows. Cellular hypoxia secondary to ischemia results in decreased ATP production, disrupts ion pump function, further promoted by a shift to anaerobic glycolysis for energy production. Activation and upregulated expression of enzymes capable of producing reactive oxygen species (ROS) and electron transport chain (ETC) dysfunction are also initiated during ischemia. These events set the stage for a burst of ROS generation when molecular $\mathrm{O} 2$ is reintroduced to ischemic tissues when the blood supply is re-established. Phagocytic Nox2 activation results in the respiratory burst of superoxide production, which further intensifies the massive oxidative stress that directly damages virtually every biomolecule found in cells and induces the programmed cell death responses, apoptosis and necroptosis. Postischemic ROS generation also activates matrix metalloproteinases (MMPs) and other proteases that act to cleave proteins and receptors, thereby impairing their function. The net impact of these ROS-dependent events is the opening of mitochondrial permeability transition pores (MPTPs), which contributes to swelling and lysis of cells. Increases in leukocyte stiffness induced by hypoxia and acidosis during ischemia lead to the impaction of these cells in capillaries, an effect that is exacerbated by ROS-dependent endothelial cell swelling which in turn reduces their diameter when the blood supply is re-established. So, a nutritive perfusion impairment becomes prominent during reperfusion, despite the repair of the precipitating ischemic event. In direct contrast to these catastrophic effects of ROS generation secondary to events occurring in ischemia and early reperfusion, oxidant production also occurs at later stages of reperfusion as tissue repair is initiated. However, ROS production occurs at lower levels that allow oxidant species to serve as signaling molecules that participate in transcriptional activation of growth factors and promote cell proliferation, differentiation, and migration. The net effect of these processes is tissue and vascular remodeling, including angiogenesis. While some of these repair processes help to restore organ function, others such as tissue fibrosis contribute overtime to eventual organ failure. The mechanisms emphasize the concept that ROS generation plays key roles in all three phases of IR injury and cell death ${ }^{6}$.

Ticagrelor is a direct-acting antagonist of P2Y12, a purinergic receptor of ADP expressed by thrombocytes. P2Y12 plays important roles in hemostasis and thrombosis ${ }^{7,8}$. It is essential for ADP-induced thrombocyte aggregation and its defects result in bleeding $^{9,10}$. Ticagrelor is, therefore, a widely used drug for the prevention of cardiovascular events and stroke ${ }^{11}$. It is reported to inhibit cellular uptake of adenosine, a purine nucleoside produced by metabolism of $\mathrm{ADP}^{12,13}$. Adenosine levels in plasma increase after inflammation, injury, or $\mathrm{IR}^{14}$. As ticagrelor inhibits the cellular uptake of adenosine, the level of endogenous adenosine concentration increases, resulting in the reduction of inflammatory markers ${ }^{15}$.

There are several commercially available anticoagulants that interfere with different stages of blood coagulation $^{16}$. Heparins are widely used, including enoxaparin, a low-molecular-weight heparin, for the treatment of ischemia and infarction ${ }^{17}$. Enoxaparin inhibits the conversion of prothrombin to thrombin and reduces the conversion of fibrinogen to fibrin, preventing clot formation. It also reduces coagulation factors and inactivates factor $\mathrm{X}^{\mathbf{1 6}}$. Enoxaparin is used to treat or prevent a type of blood clot called deep vein thrombosis (DVT), which can lead to blood clots in the lungs (pulmonary embolism). A DVT can occur after certain types of surgery, or in people who are bed-ridden due to a prolonged illness. Enoxaparin is also used to prevent blood vessel complications in people with certain types of angina (chest pain) or heart attack $^{18}$.

As mentioned above, IR causes fibrosis, and enoxaparin has anti-fibrotic effects on animal fibrosis models shown in previous studies ${ }^{19}$. Therefore, we aimed to evaluate the effect of ticagrelor and enoxaparin pre-treatment, in rats, for the prevention of abdominal aorta IR-induced lung injury. To detect these alterations, we examined the histologic sections of all lungs belonging to all groups in addition to caspase-3 immunoreactivity by light microscope. 


\section{METHODS}

\section{Experimental animals}

Kocaeli University Animal Experiments Local Ethics Committee (KOÜ HADYEK:KOÜ HADYEK:1/9-2016) approved this study, and the experiments complied with the established guidelines for animal care. Thirty-six mature male Wistar albino rats weighing 350-400 g were randomly divided into four groups as follows: group 1 (sham-control), group 2 (control-saline+IR), group 3 (ticagrelor+IR), group 4 (enoxaparin+IR). The rats were initially anesthetized with intraperitoneal ketamine hydrochloride (Ketalar; Pfizer, Istanbul, Turkey), $100 \mathrm{mg} /$ $\mathrm{kg}$ body weight. The animals were given $0.1 \mathrm{ml} / \mathrm{kg}$ normal saline in group 2, and a single dose of 25 $\mathrm{mg} / \mathrm{kg}$ ticagrelor (Brilinta-Astra-Zeneca, Södertalje, Sweden) in group 3 , orally, via gastric gavage while a single dose of enoxaparin $(0.75 \mathrm{mg} / \mathrm{kg})$ was administered via subcutaneous injection just before the ischemic period. Except for group-1, IR injury was induced by clamping the aorta infrarenally for $2 \mathrm{~h}$, followed by $4 \mathrm{~h}$ of reperfusion. Cessation of arterial flow was confirmed by the absence of an audible continuous-wave Doppler signal. The rats were euthanized with a lethal injection of sodium thiopental (Pentothal Sodium, Abbot, Italy) after 4 $\mathrm{h}$ of reperfusion. Then, the lungs of the rats were removed through midline sternotomy and washed with $0.9 \%$ saline solution for tissue processing.

\section{Hematoxylin and Eosin (H\&E) Staining}

The lungs were removed and fixed with \%10 neutral buffered formalin solution and, after tissue processing, embedded into paraffin for histological examinations for all rats. Paraffin sections $(4 \mu \mathrm{m})$ were prepared and then stained with Hematoxylin and Eosin (H\&E) for routine histologic examination. Lung damage was evaluated by histological changes ${ }^{20}$. Tissue injury of the lungs was assessed according to the structural integrity of the alveolar wall, disorganized epithelial cells, alveolar hemorrhage, inflammatory cell infiltration, and alveolar wall thickening.

\section{Caspase-3 immunohistochemical (IHC) stain-} ing and analysis

Apoptotic cells were detected by caspase-3 immunoreactivity. After deparaffinization and rehydration, all sections were incubated in $0.1 \mathrm{~mol} / \mathrm{L}$ sodium citrate buffer ( $\mathrm{pH} \mathrm{6.0)} \mathrm{in} \mathrm{a} \mathrm{microwave} \mathrm{oven}$ (medium-low temperature) for 5-7 min. Endogenous peroxidase was blocked by $3 \% \mathrm{H}_{2} \mathrm{O}_{2}$ in PBS 15 min and again washed three times in PBS. Sections were incubated in a blocking serum for 15 mins at room temperature to block non-specific binding. For immunostaining, a primary anti-Caspase-3 monoclonal antibody (74T2, Life Technologies) at a dilution of 1.100 overnight was applied at room temperature in a humidified chamber. Sections were washed three times in PBS and incubated with the biotinylated secondary antibodies (ab80437, Abcam) for 20 mins at room temperature. After three washes with PBS, the sections were incubated with peroxidase-labeled streptavidin for $15 \mathrm{~min}$. The peroxidase activity was visualized with DAB for Caspase-3. All incubations were performed in a humidified chamber at room temperature using PBS for washes between incubation steps. The sections were counterstained with Mayer's hematoxylin and mounted with entellan on glass slides. All samples were treated following exactly the same protocols. Two independent observers, who were blinded to this study, evaluated the staining semi-quantitatively. Apoptosis was evaluated based on spread and intensity of caspase-3 (+) immunoreactivity in ten random fields in each section (no expression (-), very weak (1+), moderate (2+), strong (3+) to very strong (4+) expression ${ }^{21}$. All slides were examined under a light microscope, and photomicrographs were taken with a Leica camera.

\section{Statistical analysis}

Caspase-3 scoring was analyzed by SPSS 21.0 statistical software and presented as mean \pm standard deviation (SD). The comparison of the mean among groups was made using ANOVA. $\mathrm{P}<0.05$ was considered to indicate statistically significant differences.

\section{RESULTS}

H\&E staining slides showed that lung tissues had a normal histological arrangement in group-1. The alveolar wall had normal structural integrity; the alveolar epithelial cells had an orderly manner with clear boundaries. There was no alveolar hemorrhage, inflammatory cell infiltration, and thickening of the alveolar wall (Figure 1A, B).

Histological alterations and lung injury such as intra-alveolar hemorrhage thickened alveolar wall, edematous septum, and inflammatory cell infiltration (mononuclear/neutrophilic cells) moderately occupying the interalveolar wall were seen in group-2. 
The structural integrity of the alveolar wall was damaged, and the alveolar epithelial cells were disorganized; leucocytes and cell shed debris were present in the alveoli (Figure 1C, D).

In group-3 and group-4, the alveolar wall had a structural integrity and the alveolar epithelial cells were arranged in an orderly manner; there was no alveolar bleeding, and only occasional inflammatory cell infiltration was seen (Figure 1E-H). Lung sections of pretreatment groups with ticagrelor and enoxaparin were better than group 2. Apoptotic cells were noticeable in the sections of group 2, and these cells were lower in the pretreatment groups (Figure 2). In group 2, apoptotic cells were significantly higher than sham-control and pretreatment groups $(p<0.01$; Figure 3). In Enoxaparin+ IR group, caspase-3 immunostaining was lower than Ticagrelor+IR group. These results indicated that lung injury score was significantly increased by IR, whereas ticagrelor and enoxaparin treatment significantly decreased lung injury score (Figure 3).

\section{DISCUSSION}

Tang et al..$^{22}$ have stated that infrarenal aortic cross-clamping is a standard procedure during infrarenal vascular operations. It often causes IR injury to lower limbs, resulting in systemic inflammatory response and damage to remote organs, particularly lungs.

Acute lung injury as a remote sequela of severe lower torso IR has been demonstrated experimentally in a process involving leukosequestration and generation of the arachidonate derivatives thromboxane and leukotriene B4. The lung injury was characterized by progressive hypoxemia, pulmonary hypertension, decreased lung compliance, and non-hydrostatic pulmonary edema, consistent with adult respiratory distress syndrome. Their report has reinforced the concept that humoral mediators generated at reflow might induce end-organ injury at a site remote from the focus of IR, and that the lung was a target organ ${ }^{23}$.

The clamp-induced increase in cardiac afterload raises mean arterial pressure, causing shifts in blood volume and increasing myocardial $\mathrm{O}_{2}$ demand, which can lead to left ventricular decompensation and failure. Visceral IR injury is a significant adverse effect of aortic cross-clamping, both in and of themselves, and because visceral ischemia can promote systemic

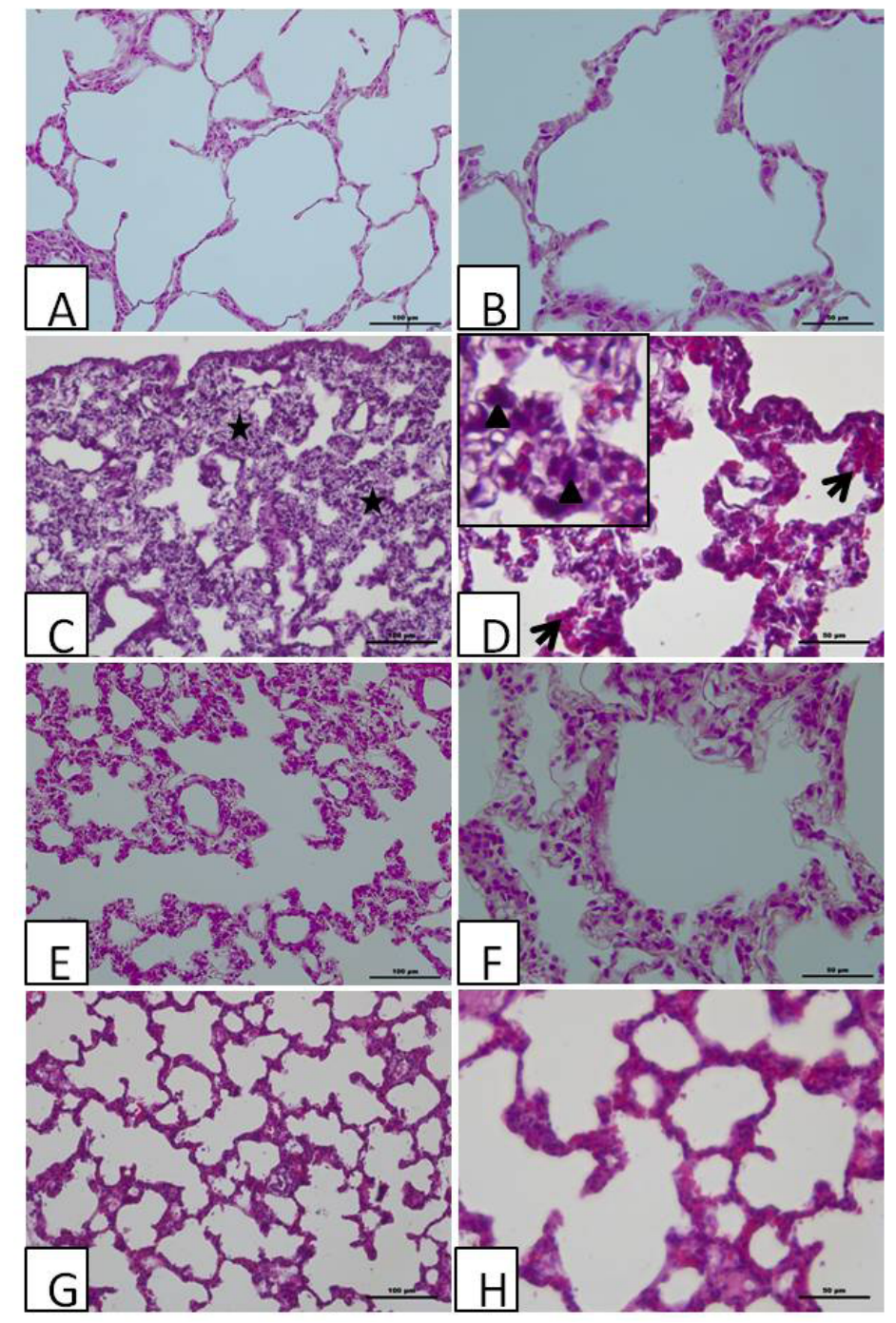

FIGURE 1. PHOTOMICROGRAPHS OF LUNG TISSUE.

Sham control (A, B); Control-Saline+IR (C, D); Ticagre$\operatorname{lor}+\mathrm{IR}(E, F)$ and Enoxaparin+IR $(G, H)$. Note the presence of intra-alveolar hemorrhage (arrows) and mononüclear/ neutrophilic cell infiltration (arroheads), thickened alveolar wall and edematous septum (asterix) in the Control-saline+IR group. Treatment groups (E-H) exhibit structural integrity and arranged alveolar epithelium. H\&E. Pictures from left column is $200 X$, right colum is $400 X$ magnification.

coagulopathy. Shunting and left heart bypass can be used to minimize the duration of visceral ischemia, while serial abdominal examinations and blood gas monitoring should be used postoperatively to detect any visceral ischemic injury'.

If we look at the operation at the cellular level; ischemia is a state where inadequate or interrupted blood flow leads to intracellular $\mathrm{O}_{2}$ depletion and a subsequent decrease in oxidative phosphorylation and ATP depletion; this situation leads to a loss of cell membrane integrity, intracellular swelling and 

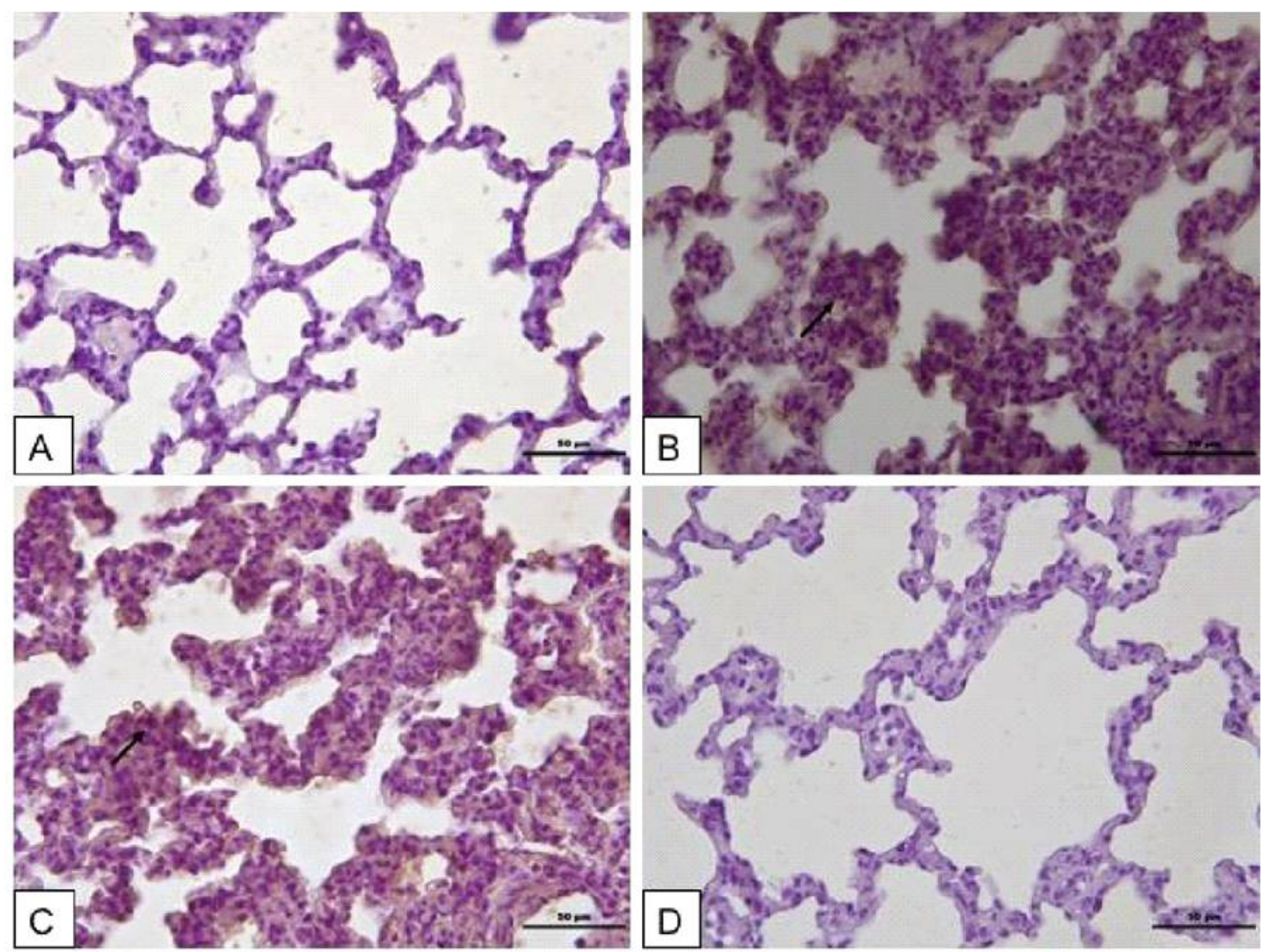

FIGURE 2. PHOTOMICROGRAPHS OF LUNG TISSUE APPLIED TO CASPASE-3 IMMUNOHISTOCHEMISTRY.

Sham-control (A); Control-Saline + IR (B); Ticagrelor+IR (C) and Enoxaaparin+IR (D) groups. Arrows indicate the caspase-3 immunoreactivity of apoptotic cells. 400X.

derangement in cellular $\mathrm{Ca}^{++}$homeostasis. Increased intracellular $\mathrm{Ca}^{++}$activates cytosolic phospholipases and proteases, leading to cell membrane disruption and activation of apoptotic and necrotic pathways ${ }^{24}$. While ischemia primes the cells for damage, the actual injury usually manifests after the restoration of blood flow and tissue oxygenation. The key mechanism of tissue injury is the intense and excessive inflammatory response to reperfusion. In general, ROS generation and complement activation occur early during reperfusion ${ }^{24}$. It has been stated that lung injury was characterized in histological sections with diffuse lung inflammation, alveolar-capillary destruction, and alveolar flooding, resulting in respiratory failure $^{25,26}$. In our histological study, we found lung injury such as intra-alveolar hemorrhage, inflammatory cell infiltration in the contol-saline+IR group. In the sections of this group, the alveolar wall was damaged, and alveolar epithelial cells were disorganized; leucocytes, cell shed debris, and apoptotic cells were present in many alveoli. In the study of Ibrahim et al. ${ }^{27}$, lungs showed normal histological structures of the bronchioles, air alveoli, and blood vessels in both groups with no histopathological alterations after injection of control and Enoxaparin. They have not observed emboli or tissue infarction, macro- or microscopically in any of the samples. In our study, the alveolar wall and epithelial cells had more structural integrity, and there was no alveolar bleeding in the pretreatment groups of Ticagrelor and Enoxaparin. Lung sections of these groups were better than those of the control-saline+IR group. Inflammatory cells and apoptotic cells were lower in the pretreatment groups of Ticagrelor and Enoxaparin.

Lu et al. ${ }^{28}$ have stated that low-molecular-weight heparin prevented cecal ligation and puncture (CLP)-induced acute lung injury in rats by anti-inflammatory coagulation. They have found that histology 


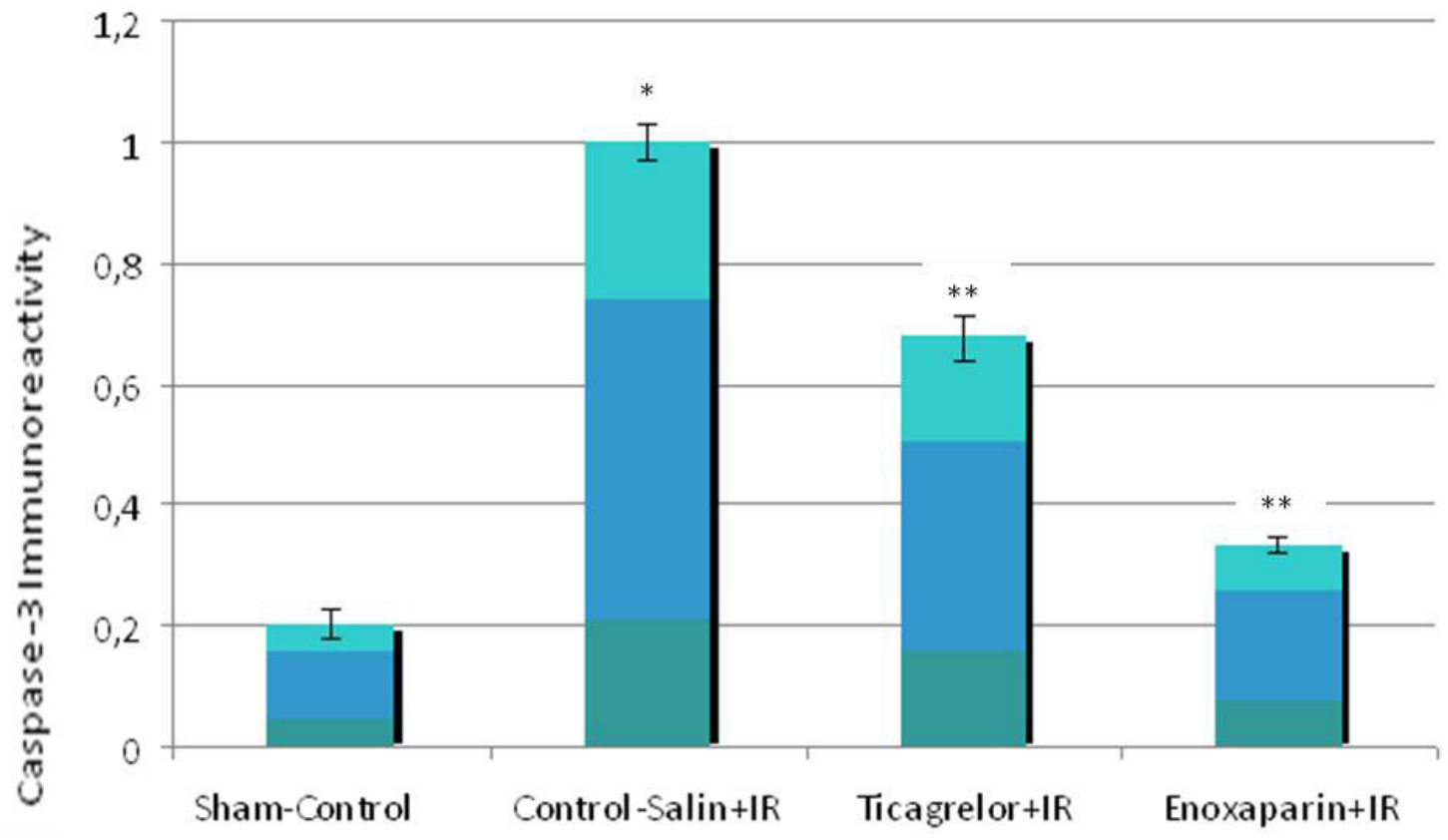

FIGURE 3. SEMIQUANTITATIVE IMMUNOLABELLING SCORE OF THE CASPASE-3 POSITIVE CELLS IN THE SHAMCONTROL, CONTROL-SALIN+IR, TICAGRELOR+IR AND ENOXAPARIN+IR GROUPS. *P<0.01 COMPARED TO SHAMCONTROL. ${ }^{* *} \mathrm{P}<0.01$ COMPARED TO CONTROL-SALIN+IR.

scores, based on the number of areas with congestion, edema, Inflammation, and hemorrhaging, were all significantly higher after the administration of CLP than in the control group, and all of the scores were lower in the pretreated group. The findings of these researchers are similar to those of our study because enoxaparin had protective effects on the lung ${ }^{28}$.

Findik et al. ${ }^{29}$ studied the effect of a ticagrelor pretreatment on the prevention of lung injury induced by abdominal aorta IR. They observed obvious changes (atelectasis, thickening of the alveolar interwall, infiltration of inflammatory cells) in the saline-IR group compared to the sham group. Their findings showed that histological changes decreased in the group treated with $25 \mathrm{mg}$ of ticagrelor compared with the saline IR and other treatment groups ${ }^{29}$. Therefore, we also studied the dose of $25 \mathrm{mg} / \mathrm{kg}$ ticagrelor and compared it with enoxaparin. Some investigators stated that heparin presented several biological activities such as anti-inflammatory action, immunological modulation, and activation of vascular endothelial growth factors, fibroblasts growth factors, and epidermal growth associated to heparin, all vital for healing ${ }^{30-33}$. In this study, light microscopic findings of the sec- tions stained with H\&E suggested that the pretreatment with enoxaparin and ticagrelor reduces the damage to the lungs in an IR rat model. Caspase-3 immunohistochemistry technique showed that the pre-treatment with enoxaparin was healthier than those of the other groups.

\section{CONCLUSIONS}

Lung sections of the ticagrelor and enoxaparin pretreatment groups were histologically similar to the healthy control group stained with H\&E. Our light microscopic findings showed that pretreatment with enoxaparin and ticagrelor reduced lung damage in the IR rat model. Pretreatment with enoxaparin, in lung tissue sections, produced better results by Caspase-3 immunocytochemistry technique. In further studies, other parameters such as ROS and inflammatory gene expressions should be evaluated for accurate results.

\section{Acknowledgments}

The current paper is a part of a project supported by Derince Education and the Research Hospital, Kocaeli, TÜRKIYE. 


\section{Author contributions}

\author{
Conception and design: OF; Analysis and inter- \\ pretation: MYY, YY, OF \\ Data collection: SFR, KK, MYY; \\ Writing the article: OF, MYY, OF, SFR;
}

Critical revision of the article: OF, MY;

Final approval of the article: $\mathrm{OF}$;

Statistical analysis: KK, SFR;

Obtained funding: $\mathrm{OF}$

Overall responsibility: OF, MYY, YY, ATK

\section{RESUMO}

OBJETIVOS: Este estudo foi realizado para revelar os possíveis efeitos protetores do ticagrelor e do pré-tratamento da enoxaparina no tecido pulmonar contra o modelo de lesão induzida por isquemia-reperfusão (IR).

MÉTODOS: Ratos albinos Wistar foram randomizados e divididos em quatro grupos: grupo 1 (controle-sham), grupo 2 (controle-salina + $I R$ ), grupo 3 (ticagrelor $+I R$ ), grupo 4 (enoxaparina $+I R$ ). Antes do período isquêmico, salina, ticagrelor e enoxaparina foram administrados nos grupos 2-4, respectivamente. Nesses grupos, a lesão de IR foi induzida pelo clampeamento da aorta na região da infrarrenal por duas horas, seguida por quatro horas de reperfusão, exceto no grupo 1. Após a sacrificação, os pulmões foram processados para exames histológicos. Secções de parafina foram coradas com hematoxilina e eosina (H\&E) para observação microscópica de luz. A apoptose foi avaliada pela imunorreatividade da caspase-3. Os dados foram analisados estatisticamente pelo programa SPSS.

RESULTADOS: Nas secções pulmonares coradas com H\&E, estrutura histológica normal foi observada no grupo 1, enquanto células epiteliais desorganizadas, hemorragia e infiltração de células inflamatórias foram observadas na parede alveolar no grupo 2. A estrutura histológica dos grupos de tratamento foi melhor que o grupo 2. Células apoptóticas caspase-3 (+) foram notadas em secções do grupo 2, e essas células foram mais baixas nos grupos de tratamento. No grupo 4, a imunocoloração com caspase-3 foi menor que no grupo 3. No grupo 2, as células apoptóticas foram significativamente maiores que nos outros grupos $(p<0,001)$.

CONCLUSÃO: Com base nos resultados histológicos, sugerimos que ambas as terapias atenuaram os efeitos prejudiciais da RI. Resultados de imuno-histoquímica com caspase-3 também revelaram que o pré-tratamento com enoxaparina proporcionou melhores resultados no modelo de lesão induzida por IR. Em estudos posteriores, ou tros parâmetros, como ROS e expressões gênicas inflamatórias, devem ser avaliados quanto a resultados precisos.

PALAVRAS-CHAVE: Pulmão. Enoxaparin. Ticagrelor. Traumatismo por reperfusão. Ratos Wistar.

\section{REFERENCES}

1. Cuzick LM, Lopez AR, Cooper JR. Pathophysiology of aortic cross-clamping. In: Chiesa R, Melissano G, Zangrillo A, eds. Thoraco-abdominal aorta: surgical and anesthetic management. Milão: Springer-Verlag; 2011. pp.65-72.

2. Klausner JM, Paterson IS, Valeri CR, Shepro D, Hechtman HB. Limb ischemia-induced increase in permeability is mediated by leukocytes and leukotrienes. Ann Surg. 1988;208(6):755-60.

3. Klausner JM, Paterson IS, Kozbik L, Valeri R, Shepro D, Hetchtman HB. Oxygen free radicals mediate ischemia-induced lung injury. Surgery. 1989;105(2 Pt 1):192-9.

4. Gyurkovics E, Aranyi P, Stagni R, Onody P, Ferreira G, Lotz G, et al. Postconditioning of the lower limb: protection against the reperfusion syndrome. Surg Res. 2011;169(1):139-47.

5. Katseni K, Chalkias A, Kotsis T, Dafnios N, Arapoglou V, Kaparos G, et al. The effect of perioperative ischemia and reperfusion on multiorgan dysfunction following abdominal aortic aneurysm repair. Biomed Res Int. 2015;2015:598980.

6. Kalogeris T, Bao Y, Korthuis RI. Mitochondrial reactive oxygen species: a double edged sword in ischemia/reperfusion vs preconditioning. Redox Biol. 2014;2:702-14.

7. Yassin MM, Harkin DW, Barros D'Sá AA, Halliday MI, Rowlands BJ. Lower limb ischemia-reperfusion injury triggers a systemic inflammatory response and multiple organ dysfunction. World J Surg. 2002;26(1):115-21.

8. Carvalho AC, Guillaumon AT, Cintra EA, Figueiredo LC, Moreira MM, Araújo S. Plasmatic vasopressin in patients undergoing conventional infra-renal abdominal aorta aneurysm repair. Rev Bras Cir Cardiovasc. 2011;26(3):404-12.

9. Cattaneo $M$. The platelet $P 2 Y_{12}$ receptor for adenosine diphosphate: congenital and drug-induced defects. Blood. 2011;117(7):2102-12.

10. Catteneo M, Schulz R, Nylander S. Adenosine-mediated effects of ticagrelor: evidence and potential clinical relevance. J Am Coll Cardiol. 2014;63(23):2503-9.
11. Wallentin L, Becker RC, Budaj A, Cannon CP, Emanuelsson $H$, Held C, et al; PLATO Investigators. Ticagrelor versus clopidogrel in patients with acute coronary syndromes. N Engl J Med. 2009;361(11):1045-57.

12. Armstrong A, Summers C, Ewart L, Nylander S, Sidaway JE, van Giezen II. Characterization of the adenosine pharmacology of ticagrelor reveals therapeutically relevant inhibition of equilibrative nucleoside transporter. Cardiovasc Pharmacol Ther. 2014;19(2):209-19.

13. Van Giezen JJ, Sidaway J, Glaves P, Kirk I, Björkman JA. Ticagrelor inhibits adenosine uptake in vitro and enhances adenosine-mediated hyperemia responses in a canine model. J Cardiovasc Pharmacol Ther. 2012;17(2):164-72.

14. Headrick JP, Lasley RD. Adenosine receptors and reperfusion injury of the heart. Handb Exp Pharmacol. 2009;(193):189-214.

15. Csóka B, Németh ZH, Rosenberger P, Eltzschig HK, Spolarics Z, Pacher P, et al. A2B adenosine receptors protect against sepsis-induced mortality by dampening excessive inflammation. | Immunol. 2010;185(1):542-50.

16. Harter $K$, Levine M, Henderson SO. Anticoagulation drug therapy: a review. West J Emerg Med. 2015;16(1):11-7.

17. Silvain |, Beygui F, Barthélémy $O$, Pollack C Jr, Cohen M, Zeymer U, et al. Efficacy and safety of enoxaparin versus unfractionated heparin during percutaneous coronary intervention: systematic review and meta-analysis. BMJ. 2012;344:e553.

18. E-MedicineHealth. Enoxaparin (Lovenox). [cited 2019 Feb 5]. Available from: https://www.emedicinehealth.com/drug-enoxaparin/article_em.htm.

19. Li Cl, Yang ZH, Shi XL, Liu DL. Effects of aspirin and enoxaparin in a rat model of liver fibrosis. World J Gastroenterol. 2017;23(35):6412-9.

20. Szapiel SV, Elson NA, Fulmer ID, Hunninghake GW, Crystal RG. Bleomycin-induced interstitial pulmonary diseases in the nude, athymic mouse. Am Rev Resp Dis. 1979;120(4):893-9.

21. Huang JS, Yang CM, Wang JS, Liou HH, Hsieh IC, Li GC, et al. Caspase-3 expression in tumorigenesis and prognosis of buccal mucosa squamous cell carcinoma. Oncotarget. 2017;8(48):84237-47. 
22. Tang B, Ma L, Yao X, Tan G, Han P, Yu T, et al. Hydrogen sulfide ameliorates acute lung injury induced by infrarenal aortic cross-clamping by inhibiting inflammation and angiopoietin 2 release. J Vasc Surg. 2017;65(2):501-8.

23. Fantini GA, Conte MS. Pulmonary failure following lower torso ischemia: clinical evidence for a remote effect of reperfusion injury. Am Surg. 1995;61(4):316-9.

24. Nieuwenhuijs VB, De Bruijn MT, Padbury RT, Barritt G). Hepatic ischemia-reperfusion injury: roles of $\mathrm{Ca} 2+$ and other intracellular mediators of impaired bile flow and hepatocyte damage. Dig Dis Sci. 2006;51(6):1087-102.

25. An J, Park SH, Ko IG, Jin JJ, Hwang L, Ji ES, et al. Polydeoxyribonucleotide ameliorates lipopolysaccharide-induced lung injury by inhibiting apoptotic cell death in rats. Int J Mol Sci.2017;18(9). pii: E1847.

26. Matute-Bello G, Frevert CW, Martin TR. Animal models of acute lung injury. Am J Physiol Lung Cell Mol Physiol. 2008;295(3):L379-99.

27. Ibrahim SS, Osman R, Mortada ND, Geneidy AS, Awad GA. Passive targeting and lung tolerability of enoxaparin microspheres for a sustained antithrombotic activity in rats. Drug Deliv. 2017;24(1):243-51.
28. LuX, Zhao L, Xu YH. Low molecular weight heparin prevents CLP-induced acute lung injury in rats by anti-inflammatory coagulation. Bosn J Basic Med Sci. 2013;13(1):50-6.

29. Findik O, Kunt AT, Yazir Y, Yardimoğlu M, Yilmaz SG, Aydin U, et al. Ticagrelor attenuates apoptosis of lung and myocardial cells induced by abdominal aorta ischemia/reperfusion. In Vivo. 2016;30(3):243-9.

30. Levine A, Kenet G, Bruck R, Avni Y, Avinoach I, Aeed H, et al. Effect of heparin on tissue binding activity of fibroblast growth factor and heparin-binding epidermal growth factor in experimental colitis in rats. Pediatr Res. 2002;5(51):635-40.

31. Street JT, McGrath M, O'Regan K, Wakai A, McGuinness $A$, Redmond HP. Thromboprophylaxis using a low molecular weight heparin delays fracture repair. Clin Orthop Relat Res. 2000;(381):278-89,

32. Michell NP, Lalor P, Langman MJ. Heparin therapy for ulcerative colitis? Effects and mechanisms. Eur J Gastroenterol Hepatol. 2001;13(4):449-56.

33. Galvan L. Effects of heparin on wound healing. J Wound Ostomy Continence Nurs. 1996;23(4):224-6. 